\title{
Beyond Predator and Prey: Figuring Corruption through Animal Metaphoric Scenarios in the Jordanian Context
}

\author{
Mohammad Abedltif Albtoush ${ }^{1} \&$ Sakina Suffian Sahuri ${ }^{1}$ \\ ${ }^{1}$ Department of English Language, Faculty of Languages and Linguistics, University of Malaya, Malaysia \\ Correspondence: Mohammad Abedltif Albtoush, Faculty of Languages and Linguistics, University of Malaya, \\ Malaysia. E-mail: Mohammad_albtoush76@yahoo.com
}

Received: April 18, $2017 \quad$ Accepted: May 15, $2017 \quad$ Online Published: May 30, 2017
doi:10.5539/ells.v7n2p110

\begin{abstract}
Combining a cognitive approach based on Lakoff's Conceptual Metaphor Theory and a pragmatic approach based on Critical Metaphor Analysis, this study investigates the use of ANIMAL metaphoric scenarios to figure corruption as a relationship between predators and prey and the cultural implications in the Jordanian context. It also seeks to identify the diverse functions performed by the use of ANIMAL metaphors. Data for the study consist of 10 excerpts taken from a satire-genre discourse "sawalief.com". My argument is that all animal metaphors in the corpus promote the contrast between the ACTIVITY of corrupters and the PASSIVITY of the citizenry and that the goal of this rhetoric is to move the PASSIVE citizenry into ACTION by shaming them into fighting corruption. This is clearly illustrated through the use of two types of ANIMAL metaphoric scenarios: ACTIVE ANIMALS representing corrupters and politicians, and PASSIVE ANIMALS representing the citizens. In addition, the use of these metaphors performs diverse functions: ideological, cognitive, and rhetorical.
\end{abstract}

Keywords: animal metaphors, corruption, Jordan, predators, prey, scenarios

\section{Introduction}

Reflecting a broader global trend, the problem of corruption has become a common topic of conversation in the Jordanian society since 2010 as reflected in the sociopolitical writings of online Jordanian news sites like Sawalief.com. This website addresses local issues (primarily corruption) on the one hand and regional matters on the other in light of the current turbulent time in the Arab world that has made corruption a major political issue throughout the world. In an interview with the author of Sawalief's editorials, he estimated that $80 \%$ of his writings address corruption due to his belief that the corrupters as well as the politicians' collusion are the main cause of problems, strikes, and unrest on the part of the Jordanian citizens who are looking for social equity, the just life, and overall reform. The focus of this research paper is on the pervasive use of different ANIMAL metaphors framing the two relevant aspects of corruption: the corrupters and politicians who are the chief cause behind this problem as well as the citizens who are the victims. Accordingly, the formula reads a victimizer-victimized relationship or an agent-patient one (Fillmore, 1968).

The data of this research is based on the satirical sociopolitical writings of the most popular Jordanian columnist Ahmad Hasan Al Zu'bi ("sawalif,") in his well-known website Sawalief.com. In his column, he utilizes various metaphorical expressions drawing from the ANIMAL semantic field in the portrayal of the corrupters and politicians on the one hand and the citizens on the other hand. Reference is made to this website in particular because of its popularity in Jordanian media discourse. Indeed, the columnist's articles have higher readership in comparison to other columnists, and he weekly posts stand-up shows on YouTube as well as on other Jordanian TV channels such as Ro'ya. He has been sued repeatedly for his satire and defended himself in the highest courts. He also enjoys the patronage of the king, who has attended his shows. The crucial objective behind such news discourse is to promote "social, economic and political philosophies... [i]t is powerful and influential, and colors and infuses the character, ideals and institutions of the individual, the family and the community" (Harris). This implies that news discourse is viewed as a rich source of linguistic data, which in turn reinforces the relationship between the columnist and the society.

In their seminal book Metaphors we Live by, (Lakoff, 1980; Lakoff \& Johnson, 1999, 2003) argue that the ubiquity of metaphor is not only a parasitic phenomenon on our daily language per se, but that it is also an intrinsic component of our thoughts and actions. In other words, the ways in which metaphors define our 
mundane realities, actions and behaviors are fundamentally governed by the conceptual system with which we are endowed and that this conceptual system is naturally metaphorically based. The CMT has become the favored means for analyzing metaphor due to its aptness at revealing the cognitive metaphors that lie beneath linguistic metaphors. In short, the CMT seems to be the most powerful and pioneering theory in the field of cognitive linguistics.

The columnist's choice of ANIMAL metaphors performs several functions, among them being to represent the corrupters and politicians in a negative light and to encourage emotional involvement with the victimized citizens. Likewise, these animal metaphors create humorous effect through the savage attack on the corrupters as well as the politicians who collude with them. However, the most significant function is to inculcate in Jordanian readers an ideological perspective through the use of these metaphors. It should be pointed out that metaphor studies in Arabic language within scenario frameworks has not been given the attention which has been attracted by other languages. For instance, the phenomenon of metaphor has been extensively examined and scrutinized in English (Howe, 1988; Lakoff, 2001; Lakoff \& Johnson, 2003; Mio, 1996; Musolff, 2004). It has also been examined in Spanish (Hellín García, 2009), and in German (Jaworska, 2011) just to mention a few. Consequently, this article significantly contributes to metaphor studies through presenting various ANIMAL metaphorical scenarios, which in turn reflect the sociocultural belief system of the Jordanian community. Indeed, the sociocultural role behind metaphor choice serves as the key factor which has to be increasingly taken into consideration (Kövecses, 2005). This implies that metaphor and culture are intertwined and never separable. Furthermore, the article is also meant to explore the various functions metaphor performs in a satire-genre discourse in Arabic (i.e., online news columns discourse). To achieve the above objectives, two main research questions are addressed: 1. What ANIMAL metaphorical scenarios are used in the discursive construction of corruption as a relationship between predators and prey? 2. What functions do ANIMAL metaphors perform in the data examined?

Having provided a brief background about the problem of corruption, the columnist whose writings are under examination, and the phenomenon of metaphor (which is used to frame an abstract target domain via a well-delineated counterpart) in the introductory section, the second section is devoted to presenting an overview of related literature on metaphor. The theoretical framework and methodology within which the data is carried out will be dealt with in section 3. Discussion of analysis and results of the study will be presented in section 4 . Finally, section 5 will close the study with conclusions and recommendations for further research

\section{Literature Review}

Scholarly interest in the linguistic phenomenon of metaphor dates back to ancient times. The key early theorist of metaphor was Aristotle. Indeed, the word "metaphor" has developed from the Greek word "metapherin" whereby the first part meta means "with" or "after" and the second part pherein means "carry" or "bear" (Charteris-Black, 2004). This indicates that metaphor is a means of transmitting attributes and meanings from one semantic domain to another. By the same token, metaphor is defined in Merriam Webster's Dictionary as "a figure of speech in which a word or phrase that is literally denoting one kind of object or idea is used in place of another to suggest a likeness or analogy between them".

Metaphor was identified by classical approaches such as Aristotle's substitution/comparison theory as a deviant phenomenon of language (Goatly, 1997; Murray \& Rosamund, 2006). This means that metaphor was viewed as an artistic or esthetic device of language, pretty much like a garment for human body. Depicting metaphor as such implies that it is superfluous to meaning, maybe even frivolous. However, this depiction is in sharp contrast with the main tenet of the conceptual metaphor theory championed by (Lakoff, 1980; Lakoff, 2001, 2003; Lakoff \& Johnson, 1999) in their landmark theory of the CMT, which argues that metaphor is primarily a matter of cognition and only afterward a linguistic feature. The crucial tenet of (Lakoff \& Johnson, 2003) theory is that "the essence of metaphor is understanding and experiencing one kind of things in terms of another". In the light of this conceptual view, metaphor is properly defined by a cross-domain mapping whereby the underlying cognitive materials and attributes of the donor source domain are screened onto the host target domain, making it eventually fully perceptible and accessible (Lakoff, 1980; Lakoff \& Turner, 1989). Drawing on the cognitive approach to metaphor, the well-known conceptual metaphor LOVE IS A JOURNEY (Lakoff, 1980), shows how our familiarity and experiential knowledge about the tangible, well delineated domain of JOURNEY enable us to better capture the abstract, poorly delineated domain of LOVE. The attributes of the source domain are projected onto the target counterpart in the sense that lovers are conceived in terms of travelers; the love relationship is perceived in terms of the vehicle used in the journey; the goals to be reached by lovers are reasoned about in terms of the destination of the journey, and finally difficulties encountered by lovers are perceived in terms of obstacles met by travelers. The upshot behind these cross-domain projections is that metaphor is a means to 
semantically bridge the gap between two disparate concepts so that what is dissimilar eventually turns out to be similar.

According to (Semino, 2008), metaphor "can provide ways of simplifying complexities and making abstractions accessible”. In political discourse for example, (Hellín García, 2009) shows how the abstract, thorny concept of TERRORISM is framed in terms of the more concrete domain of FIGHTING in the speech of the Spanish president. This conceptualization and hence personification of TERRORISM in terms of an ENEMY does not only imply two fronts that are met in a battle field scenario, but also an ADVERSARY which has to combated and killed. The central point in this connection is a call for immediate action rather than merely identifying TERRORISM as an ENEMY. Consequently, the president's use of metaphoric expressions belonging to the domain of FIGHTING performs three concurrent discourse functions. Cognitively, he used metaphoric expressions originating from the concept of fighting to bring greater definition to the abstract concept of “terrorism." Rhetorically, he personified terrorism as if it were an adversary and thus encouraged peoples' desire to beat it. Lastly, the president's use of metaphoric expressions performed an ideological function through which he disseminated his anti-terrorism agenda to appease people. In conclusion, metaphor choice is a powerful communicative tool employed by language users and is never a value- free device utilized in a given discourse. As pointed out earlier, metaphor choice is crucially motivated by the culture in which it occurs. For example, positive evaluations in American political discourse are framed in terms of LIGHT and FIRE metaphors due to America's revolutionary history. However, positive evaluations within the British political discourse are shaped in terms of the donor source domain PLANTS because of the British gardening tradition (Charteris-Black, 2004).

Culturally motivated metaphors are apparent in(Torlakova, 2014) in which she argues that Al-Jazeera commonly utilizes the terms "revolution" and "revolutionaries" to mobilize the uprisings taking place in Tunisia, Egypt, Yemen, Libya and Syria. The linguistic metaphors of the study are classified under the respective conceptual metaphors to which they belong such as JOURNEY, SEASONS OF THE YEAR, FIRE and the like whereby the culture-specific metaphors which are examined in the corpus are motivated by Islamic traditions and people's cultural experiences.

(Musolff, 2006) argues that the notion of scenario is an intrinsic component of studying metaphor. He argues that mapping elements from the source domain into the target counterpart is an incomplete task. Consequently, studying metaphorical expressions should be handled within scenario framework whereby the goals, actions, participants, entities and setting are involved (Semino, 2008). Her stipulation is attributed to the fact that scenarios enhance evaluative and attitudinal attributes relevant to the discourse community in question. Moreover, scenarios explored by (Musolff, 2006) reveal a rich ontological structure whereby human beliefs, perceptions, goals and actions are projected onto target domains as if they were a mini-narrative. In his analysis of the metaphorical language in public discourse, (Musolff, 2006) shows how the LOVE-MARRIAGE-FAMILY scenario is mapped onto members of the European Union (EU). The story line through which the EU is conceptualized proceeds along the same steps as starting a family. For instance, the relationship between couple proceeds through flirting, engagement, marriage, having children, marital problems and finally divorce. (Musolff, 2006) highlights a cultural dimension of metaphor whereby the male-centeredness bias holds for the German and British side, who were figured as flirting with France.

Moreover, (Jaworska, 2011) investigated how the BODY-ILLNESS-CURE scenario is screened onto imperceptible political matters. Her study concerns the German people who are framed in terms of a host body embracing the Polish minority, which is conceived in terms of a foreign body causing illness to the German state. Therefore, the only cure for this illness is either to Germanize the Poles or to eradicate them. In short, the scenario crystalizes the ethnic ideology of the Germans toward the Polish people whereby thistendency is similar to their anti-Semitic ideology towards the JEWS who are figured out as a PARASITE.

Lastly, a cross-cultural study of animal metaphors shows how the attributes and behavior of animals are mapped on those of people (Talebinejad \& Dastjerdi, 2005). The authors selected 44 animal metaphors in English and Persian and compared the way they are interpreted metaphorically by native speakers. The framework within which comparison is conducted is "THE GREAT CHAIN OF BEING" metaphor (Lakoff \& Turner, 1989) as well as (Kövecses, 2002) notion of "metaphorical highlighting". Findings of this cross-cultural study reveal that $75 \%$ animal metaphors in both languages are similar, but $25 \%$ of them do reflect a culture-specific model.

\section{Theoretical Framework}

The current study combines two metaphor theories which are considered to be pioneering in the field of cognitive linguistics and critical discourse studies -the conceptual metaphor theory (CMT) ( Lakoff, 1980) and the critical metaphor analysis (CMA) (Charteris-Black, 2004). This is because the former is an adequate 
analytical framework within which linguistic metaphors are made distinct from their conceptual counterparts and the latter has the potential to exhibit the pragmatic and discourse implications behind metaphor choice. The basic tenet of the CMT is that our perception of the world is intimately mirrored in our thoughts, which are metaphorically shaped. As the title of (Lakoff, 1980) book, Metaphors we Live By suggests, comprehending the world we live in stems from the metaphors that we use in our daily life.

Moreover, (Kövecses, 2005) has asserted that metaphor has cross-cultural and intra-cultural dimensions. Accordingly, every culture has its own way of conceptualizing the addressed target topic. At the same time, though, (Lakoff, 1980) and (Kövecses, 2005) have emphasized that conceptual metaphors are also outcomes of human embodied experiences owing to universal human physiology and bodily experiences such as emotions and diseases despite the differences that may hold amongst different cultures. However, (Charteris-Black, 2004) argues that, although a powerful theory in the field of cognitive linguistics, the CMT suffers certain problems in that the examples provided by Lakoff \& Johnson are invented and not contextually attested. There should be a complementary theory of context (critical metaphor analysis) whose main task is to explain why the occurrence of metaphoric expressions in any given discourse makes them ultimately persuasive to discourse recipients.

The CMA is a pragmatic approach emphasizing that context is a determining factor behind the meanings of metaphors. Charteris-Black maintains that the CMA is an integrationist approach in which linguistic, semantic, cognitive and pragmatic criteria are involved. This implies that since metaphor has various aspects, then its explanation in a discourse cannot be accounted for by just one criterion. Metaphor analysis within this model proceeds via three phases: The first step is metaphor identification, in which candidate linguistic metaphors and metaphor key words are identified. To do so, Charteris-Black introduced the notion of "semantic tension" as a proper defining strategy of linguistic metaphor in a given discourse. Building on this notion, (Charteris-Black, 2004) holds that metaphor is "a linguistic representation that results from the transfer of a word or phrase from the context or domain in which it is expected to occur to another context or domain where it is not expected to occur, thereby causing semantic tension". Within this phase, conceptual metaphors are inferred or generalized from their surface counterparts and (if feasible) conceptual keys are also inferred from the respective conceptual metaphors. The second step is the metaphor interpretation phase, which is concerned with mapping elements between the source and target domains as well as the contextual meanings of metaphors. The final step is metaphor explanation phase, which is mainly concerned with uncovering the purpose behind metaphor choice in a certain context. This third stage has to do with revealing the social role metaphor plays in a discourse in order to persuade addressees. Methodologically, the study is mainly qualitative due to the exploratory nature of the questions pursued. The data is taken from a well-known web site sawalief.com in the mainstream Jordanian newspaper alrai'. For this purpose, only linguistic metaphors belonging to the ANIMAL semantic field are selected. It should be pointed out the assembled animal metaphors can best be categorized in terms of active animals/predators representing the corrupters and politicians on the one hand, and passive animals/ victims representing the Jordanian citizens on the other hand. The data under investigation consists of 10 excerpts, of which 7 extracts represent the former category and three extracts represent the latter. Using close reading, the 10 extracts are analyzed to identify the candidate linguistic metaphors. As is the case with all metaphor studies, the style convention of metaphorical language followed in the present study is that metaphorical expressions are marked in italics, but capital letters hold for their respective conceptual counterparts. Linguistic metaphors in the original Arabic version are, however, underlined.

\section{Results and Analysis}

The use of ACTIVE ANIMAL metaphors in framing the corrupters and politicians will be presented first and followed by PASSIVE ANIMAL metaphors, which frame the citizens. Therefore, the linguistic metaphors investigated in the current research perform a representation function (Chilton, 2004) whereby the presence of an agent who is the doer or instigator of the action (i.e., the corrupters) implies a patient counterpart (i.e., the citizens) who undergoes the action (Fillmore, 1968). The importance of ANIMAL metaphors is emphasized by (Zoltán, 2002) who holds that "much of human behavior seems to be metaphorically understood in terms of animal behavior".

\section{Predators'/Active Animal Scenarios}

Apart from the general conceptual metaphor: HUMANS ARE ANIMALS, the use of aggressive/active animal metaphors in extracts 1-7 to frame the corrupters and politicians leads us to argue for inferringdeeper conceptual metaphors represented by: CORRUPTERS/POLITICIANS ARE PARASITES, CORRUPTERS/ POLITICIANS ARE PREDATORS and POWERFUL IS UP/ ACTIVE.

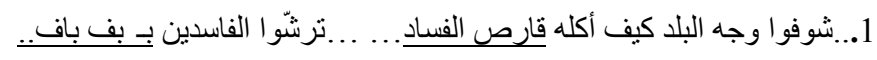


1). Look at the face of the country how it has been eaten by the flea of corruption. Spray the corruptors with Pif-Paf.

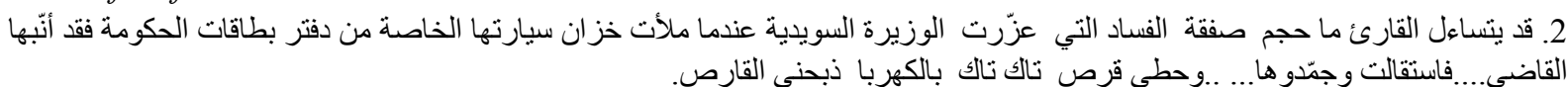

2). The reader may wonder about the small size of corruption committed by the Swedish minister when she filled her private car tank with oil using the government's credit card and hence she was questioned by a judge and pushed to resign. Oh! Use insecticide. The fleas are killing me.

Linguistic metaphors in (1) and (2) above originate from the basic conceptual domain of ANIMALS. Since the target domain addressed is the corruptors, the conceptual metaphorical pattern: HUMANS ARE ANIMALS is inferred. Fleas are small insects that suck people's blood when they're not paying attention, so the scenario portrays corruptors as those who siphon the country's life-force while citizens remain unaware. People's blood corresponds to the country's wealth, fleas to corruptors and the act of fleas' sucking blood to corruptors' siphoning the country's wealth, which functions as the highlighted theme. In (1), the columnist personifies the country and urges the public to realize that the embezzlement of the corrupters is ugly and distorting - just as one's face is distorted and made ugly by fleas' bites. Indeed, the columnist's use of "face of the country" in (1) has a close cultural connection with SHAME. Humorous effect stems from dehumanizing the corrupters into tiny and tacky insects, which are killed by a spray called Pif-Paf. Therefore, satirizing them as such implies a pungent attack, which is only carried out by the Pif-Paf spray. Similarly, the humorous effect involves the Jordanian citizens who get their face deformed by corruption. Likewise, in (2), the columnist compares corruption in Sweden and Jordan using the example of a Swedish minister who simply filled her private car with gasoline paid for by a government credit card. As a result she was interrogated before a judge and then forced to resign. In comparison, the corrupters in Jordan are figured many and their acts are figured as much more scandalous and outrageous compared with the Sweden minister's tiny act. The vigorous Swedish response, like the use of insecticide against annoying insects, is praised because even small acts of corruption can add up. The public is encouraged to adopt a zero-tolerance approach to corruption as the corrupters are dehumanized.

$$
\text { }
$$

3). Not a few months go by but that $a$ whale escapes or a ship gets away.

$$
\text { 4.منى سنقول للحيتان الفالتة » خالصلكو بالوطن《!! ومنى سنطيل منعة الفقير قليلاً...متى؟؟؟؟؟؟ }
$$

4). When will we say to the unbridled whales: take the whole country? When will we increase the pleasure of the poor a bit.... When?

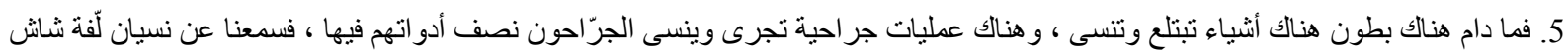

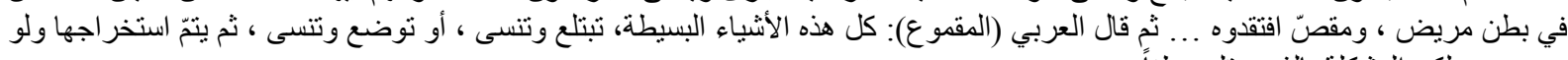

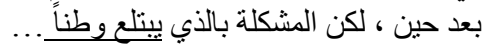

5). As long as there are bellies, there are also things which are swallowed and forgotten. There are surgical operations where surgeons forget their tools in the patients' bellies such as a piece of cloth or pairs of scissors. The oppressed Arab said: all these simple things are installed and forgotten, then extracted at any time. Nevertheless, the problem resides in he who swallows a country.

Corrupters in examples (3) and (4) are portrayed in terms of a whale, which is an animal living in the seas and oceans and that swallows smaller creatures. The whale in the Jordanian folk literature is a symbol of power. The old generations had the myth that the moon was swallowed by a whale when there was a lunar eclipse, so they tended to empty their dishes in hope that the whale might release the moon (Al-Uziazi, 2012). Likewise, whales are associated with swallowing smaller creatures, like the prophet Yunus, in the Holy Quran (As-SafaatSura, p. 142). However, this expression has only recently been used as a brand new metaphor to symbolize those who rob the country's resources. This all implies that it must be a very large agent that is swallowing such a great amount of the country's wealth. In (3) and (4), corrupters are never controlled by the government or questioned before justice, rather they are set free. Eventually, the collusion on the part of the government to interrogate them left the hopeless citizens with the only option of submitting the country to the corrupters. The same scenario recurs in (4), but within a comparative style through which a humorous metaphorical function is performed. It often happens that pairs of scissors or a piece of cloth are forgotten, due to a medical mistake, in patients' bellies after being undergone surgical operations. The crucial point is that there extracting these little things will never be a problem when compared to the problem of swallowing the country. This concrete scenario is then projected into the situation of the corrupters whereby the country's wealth is subsumed in their bellies. Consequently, the highlighted theme implies the impossibility of extracting the country's vast resources after being swallowed by those who siphoned 
them.

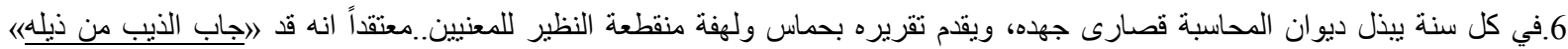
اللاولة ... لكن ما ان يعود الرجل الى ديو انه ، حتى يطبطبون على 》الذيب و ذيلهي/ ثم يطلقونه من جديد ليأكل حلال الوطن.

6). Each year, the audit bureau does its best and presents its reports with unprecedented enthusiasm... assuming that it brings the wolf by its tail. Yet, as soon as the employee returns to the bureau, the officials pat the wolf on its tail and release it again to eat the country's resources.

In this scene, corrupters are negatively embodied in terms of a more treacherous, malignant, monstrous and aggressive animal (i.e., the wolf) (Al-Jahiz, 2010). Consequently, Al-Jahiz stipulates that the Arabs describe a person who has the above characteristics by saying that he is more malignant than a wolf. These perceptions of the wolf are carried over and extended to Jordanian folk literature (AL-Uziazi, 2012). The context of the wolf's scenario is projected into the Jordanian Audit Bureau, whose mission is to observe and question those who violate laws of the state around embezzlement and the siphoning of money. The wolf in Jordanian folk literature is identified as a monstrous animal that shows up on dark nights and preys on people's livestock, primarily goats and sheep (Al-Uziazi, 2012) (Ibn Al-Muqaffa, 2010). This type of structural metaphor is screened onto the corrupters, who are brought and interrogated before the bureau's officials due to their robbing the country's resources. However, instead of punishing them, they get praised and released again to embezzle other resources. Collusion on the part of the officials functions as the crucial theme behind this metaphoric scenario.

7. أخشى إذا ما يأسنا من استرجاع ما سرقته لحصينياته الفساد أن نقول لهم في نهاية المطاف: 》خلص خذوهن صدقه عن روح

$$
\text { أمو اتنا...مسامحينكوش). }
$$

7). I am afraid if we are desperate to retrieve what has been robbed by the foxes of corruption, we will eventually tell them: take it as charity on behalf of the soul of our dead. We will pardon you.

The fox scenario is quite close to that of the wolf in terms of being predators on weak animals, especially late on dark nights. In both cases, the fox and the wolf occupy superior positions whereby they devour and crush those weak animals that hold an inferior position. As such, (Al-Jahiz, 2010) maintains that life in the animal kingdom is a struggle for survival. Unlike goats and sheep, which are the victims of wolves, hens are the target victims for foxes in this scene. Consequently, based on (Lakoff, 1980) ontological correspondences, if corrupters correspond to foxes, then the country's resources correspond to the hens and the act of predation on dark nights corresponds to the corrupters' actions while the citizens are not paying attention. Foxes are best known for their slyness, cunning, tricks, deception, villainy, and untrustworthiness from the Jordanian cultural perspective (Ibn Al-Muqaffa's, 2010) (KalilahWaDimnah) (Al-Uzaizi, 2012), (Al-Jahiz, 2010).

It has been noted that the ANIMAL scenarios of the above extracts perform several metaphorical functions in the light of (Drew \& Holt, 1998). First, these scenarios express a harsh attack on the corrupters by dehumanizing them, demoting them from their original status as human beings into the status of animals. Being reduced from human status to animal status represents a loss of status in terms of "the great chain of being" (Lovejoy, 1936). Second, these scenarios create humor by screening animals' behaviors onto the corrupters' and hence conveying the intended meaning in a manner reminiscent of Jordanian folk literature. Third, these scenarios articulate the ideological dimension and perspective of metaphor (Van Dijk, 1998) by presenting the sociocultural belief systems and values of the Jordanian community. A function as such confirms the notion of "persuasiveness" in the third phase of the critical metaphor analysis (Charteris-Black, 2004)). Fourth, closely related to fulfilling the ideological function of metaphor, these scenarios contribute to what has been called "discourse systematicity" (Cameron \& Low, 1999) whereby all of the linguistic metaphors that are used correspond. In this case the depiction of the corrupters in the satire-genre discourse is drawn from the semantic domain of ANIMALS.

Scenarios of Citizens' Passivity

In what follows are passive animal metaphors used to shape the victimized citizens in terms of two deeper conceptual metaphors: CITIZENS ARE PASSIVE VICTIMS/ PREY and POWERLESS IS DOWN/PASSIVE.

8. سنوات ونحن ندفع الثمن للحكومات...جعلونا فئران تجارب لسياستهه و أفكار هم ورضينا...جعلونا مطية للضر ائب ورضينا...وذلو لاللصندوق

الدولي ورضينا...

8). For years, we have been paying the price to the government. They have made us laboratory mice for their policies and ideas. They have also made us a beast of burden for their taxes and it satisfied us, and camels for the international monetary fund and it satisfied us.

Contrary to the aggressive animal metaphors that are used to conceptualize the corrupters in the preceding sub-heading, Jordan's citizens are conceptualized as prey and passive animals that undergo harsh treatment and 
exploitation. Therefore, the conceptual metaphors CITIZENS ARE PREY and CITIZENS ARE PASSIVE can be inferred. Victims' scenarios read as a cause-effect relationship in the sense that the outcome of the corruption caused by the corrupters is the responsibility of the citizens who have been made the government's budget sponsors for a long time. More significantly, the columnist uses the object pronoun (us) to indicate the inclusiveness of all the citizens as well as himself as a spokesperson of their worries. This use of (us) makes this self-deprecating humor, which further indicates a culturally specific feature to the degree that self-deprecation, is believed to protect against the sins of pride and elitism. Animal metaphor clustering is apparent through the use of three linguistic metaphors: mice, beasts of burden and camels respectively.

First, the citizens are structurally embodied in terms of a tiny, mild animal, namely the mice which in turn symbolize triviality and silliness. Laboratory experiments are usually conducted on mice as field tests rather than on human beings. This fact complies with "Great Chain of Being Metaphor" in which human beings occupy the highest level in the hierarchy which reads as HUMAN BEINGS, ANIMALS, PLANTS, COMPLEX OBJECTS and NATURAL PHYSICAL THINGS respectively (Lakoff \& Turner, 2009), (Lovejoy, 1936). Consequently, it can be inferred that mice are valueless and occupy a low position when compared to human beings who occupy the highest level in the hierarchy. Nevertheless, the negative consequences of corruption, which are mainly represented by the corrupters' siphoning the country's wealth, has made the politicians impose their unjust decisions upon the citizens as the only outlet to make up for the budget deficit. From the Jordanian folk literature perspective, mice symbolize weakness, levity and disposable animals whose death is trivial (Al-Uziazi, 2012) (Ibn Al-Muqaffa, 2010). The weakness of the mouse is exemplified by the Jordanian proverb in which cats usually chase mice whenever the latter shows up: "when the cat's away, the mouse will play". Accordingly, this implies that when fathers are away from home, sons invest their absence in terms of being ACTIVE and not abiding by their mother's instructions. Nevertheless, in the presence of their fathers, they turn out to be well-behaved and PASSIVE sons. Therefore, metaphoric choice of mice stems from their weakness and thus their usefulness in laboratory experiments. Evidence from the science field holds that mice are the most common animals for scientists to conduct their experiments on due to the fact that certain bodily processes such poisonous effects and proteins are similar between mice and human beings (Zhang et al., 2010). This in turn justifies their use as test fields and hence their cheapness in comparison with people. Ontologically, the Jordanian citizens have been abused for a long time by the politicians who collude to bring the corrupters before justice.

The beast of burden metaphor on the other hand implies the animal that is ridden by people and carries their luggage (Manzur, 1997). He holds that luggage is attributed to heavy loads which people are no longer able to carry over a long distance. Based on this definition, the crucial theme behind the scene is that the citizens are the beast and taxes are the heavy luggage that they carry over a long time with their complete submissiveness. However, the scenario extends to involve the camel as a larger animal capable of handling further heavy loads such as people's tents, wheat, luggage...etc when departing from one place to another in the deserts (Al-Uziazi, 2012). He contends that camels symbolize patience (as they have the capability of being thirsty for three months) and endurance (as they are also able to endure heavy burdens). Indeed, Al-Uziazi adds that camels in the Arab culture are called "ships of the desert" and they are the only means for crossing long distances in the deserts. This concrete scene is screenedonto the citizens, who are forced by decision-makers (i.e., the politicians) to pay off the country's debts through further taxes on their living. So, taxes are figured as the heavy loads carried by camels and the enduring persistence of such taxes on citizens are conceived in terms of the long distance crossed by camels.

According to (Semino, 2008) extended linguistic metaphors are one particular type of cluster where the above metaphoric expressions: mice, beasts of burden and camel are evoked by the ANIMAL semantic field. Moreover, they highlight the target topic under discussion (i.e., the citizens) more vividly through their close proximity in the extract (Goatly, 2007). Indeed, since the citizens are framed in terms of animals that undergo actions exemplified by laboratory experiments and carrying loads, then the conceptual metaphors POWERLESS IS DOWN, LESS IS DOWN and DOWN IS BAD can be inferred. Meanwhile, decision-makers or politicians are figured through the conceptual metaphor POWERFUL IS UP. Metaphorical functions are apparent through the negative representation and evaluation of citizens by means of downplaying and ridiculing their status into mere submissive animals. Likewise, another conspicuous function involves delegitimizing the role of politicians who set free the corrupters while abusing and humiliating the citizens unjustly. Indeed, it is the issue of dehumanization that is closely connected with the author's attempt to build emotional involvement with and the citizens - and hence an indirect call for liberation and moving the citizens from passivity to action.

$$
\text { 9. و لأن المو اطن جمل المحامل الاقتصادية و السياسية و الليير الية و التجريية...فهو مطالب بسد عجز لم يكن سبياً في تفاقده }
$$

9). Because citizens are the camels of experimental, liberal, political and economic burdens, they are required to 
bear the shortfall that they are not responsible for.

The camel scenario recurs again to further highlight the long lasting suffering of the Jordanian citizens as per the economic situation in particular. As mentioned earlier in the Jordanian folk literature, since camels are the animals most favored for handling heavy loads, then it follows that the negative consequences of corruption are the citizens' responsibility. The theme of injustice is crystalized in this context in that instead of bringing the main culprit of corruption (i.e., the corrupters) before justice, the Jordanian citizens are the ones forced to bear the burden. As the citizens are undergoing the governments unjust actions, the conceptual metaphorical patterns: POWERLESS IS DOWN, whereas POWERFULL IS UP holds for the government.

10. عذّ عن قرارك الآن... ما دام الوطن بين أيدينا.قبل أن تعود عنه... و الوطن بأيدي الفوضى... و لا تحاول أن تجر عربة الاقتصاد بهذه الطريقة فالثعب لن يكون كبش فداء الفساد..

10). Return to your decision now......as long as the country is between our hands......before returning it....... and the country is in the hands of chaos...do not try to drag the wagon of economy on this path.......because? The people will never be scapegoats for corruption

In Jordanian folk literature, a scapegoatis defined as an animal sacrifice that is slaughtered on behalf of other animals and has metaphorically extended to denote the act of punishing someone on behalf of the larger group (Al-Uziazi, 2012). Again this linguistic metaphor recurs in this context whereby it originally draws from prophet Ibrahim's story with his son Ismael. The prophet Ibrahim was ordered to sacrifice his cherished son (Ismael), and was willing to do so, but Allah gave him a sheep instead (As SaffatSura: verse 102). The columnist opposes the government's decision of blaming the Jordanian people for what the corrupters have done. By analogy with this experiential scenario, the columnist argues that the economic situation will not be improved by imposing taxes on the citizens, high prices, unemployment and the like.

\section{Conclusion and Recommendations}

Apart from having the general conceptual metaphorical pattern: HUMANS ARE ANIMALS, which was used as the basis for drawing this data set from the larger corpus of metaphors found in Zubi's column, a deeper analysis of the ten excerpts has revealed that the agent-patient elements of corruption are represented by two types of animals, which correspond to the categories of "the corrupters" and "the citizens." First, the corrupters and politicians are conceived in terms of aggressive/active animals like predators and parasites. Therefore, the conceptual metaphors that can be inferred are: CORRUPTERS/POLITICIANS ARE PREDATORS, CORRUPTERS/POLITICIANS ARE PARASITES and POWERFUL IS UP/ACTIVE. Meanwhile, the citizens are framed in terms of passive animals. Implicitly and explicitly, Zubi argues that citizens are victimized (parasitized and preyed upon) by the corruptors. Here, the corresponding conceptual metaphors include CITIZENS ARE PASSIVE VICTIMS/PREY, POWERLESS IS DOWN/PASSIVE and DOWN IS BAD.

Another conclusion of the arguments in the study is devoted to the various functions performed by the use animal metaphor choice. First, the metaphors perform an ideological function in that ANIMAL metaphors reflect Jordanians' ideological perceptions of animals' behaviors and hence map the latter'sbehaviors onto people. Animals are believed to lack human morals and engage in a struggle for survival where the strong exploit the weak. To compare human affairs to those of animals is to portray humans as failing to live up to their natural and/or God-given potential in terms of the "Great Chain of Being." Second, the metaphors perform a rhetorical function by attacking the corrupters and delegitimizing the politicians' role insofar as they collude with them. At the same time, the columnist's use of the inclusive pronouns "we" and "us" in conjunction with passive animal metaphors conveys the columnist's emotional involvement with the POWERLESS citizens who are conceptualized as PASSIVE VICTIMS.

The columnist critiques the shamefulness of the corruption tolerated by a passive citizenry while being careful not to distance himself from the people in the hopes of shaming them into joining him in action. Third, the metaphors perform a cognitive function, which is performed by projecting various types of animals belonging to the more concrete conceptual domain of ANIMALS onto the relationship between the corrupters and citizens. This has the potential to bring greater clarity to the concept of "corruption" in the minds of the citizenry. Finally, the metaphors perform a humorous function whereby the choice of animal metaphors satirizes Jordanian politics by ridiculing both corrupters and citizens and downgrading them to the status of mere animals. This follows a common pattern where laughter is provoked through metaphors that liken aspects of normal everyday life to grotesque doings and beings (i.e., by comparing humans to "lower" animals). As a recommendation for future research, it would be interesting to analyze how the victimhood of Jordan's citizens, its economy, and the country as a whole are figured by Zubi through metaphorical scenarios that project current events onto conceptual domains other than ANIMALS. Furthermore, it is also interesting to figure out another bulk of 
culture-specific metaphors originating from ANIMAL domain in the conceptualization of local political malpractices represented mainly by the Jordanian government and politics.

\section{References}

Al-Jahiz, A. O. (2010). Kitaab Al-Hayawan, The book of animals.

Al-Uziazi, R. (2012). Ma'lamat At-Turath Al-Aurduni, The Jordanian folk literature (part 1).

Cameron, L., \& Low, G. (1999). Researching and applying metaphor, 41. Cambridge: Cambridge University Press.

Charteris-Black, J. (2004). Corpus approaches to critical metaphor analysis. New York: Springer.

Chilton, P. (2004). Analysing political discourse: Theory and practice. London: Routledge.

Drew, P., \& Holt, E. (1998). Figures of speech: Figurative expressions and the management of topic transition in conversation. Language in society, 27(4), 495-522.

Fillmore, C. J. (1968). Toward a theory of deixis.

Goatly, A. (1997). The Language of Metaphors: Literal Metaphorical. Taylor \& Francis US.

Goatly, A. (2007). Washing the brain metaphor and hidden ideology, 23. Amsterdam: John Benjamins Publishing.

Harris, J., Leiter. K., \& Johnson, J. (1977). The Complete Reporter: Fundamentals of News Gathering, Writing and Editing. New York: Macmillan Publishing Company.

Hellín, G., \& María, J. (2009). Fight metaphors in Spain’s presidential speeches: JL Rodríguez Zapatero (2004-2007).

Howe, N. (1988). Metaphor in contemporary American political discourse. Metaphor and Symbol, 3(2), 87-104.

Ibn Al-Muqaffa, Kalila wa Dimna, avialable online.

Jaworska, S. (2011). Anti-Slavic imagery in German radical nationalist discourse at the turn of the twentieth century: a prelude to Nazi ideology? Patterns of Prejudice, 45(5), 435-452. http://dx.doi.org/10.1080/0031322X.2011.624762

Kövecses, Z. (2002). Emotion concepts: Social constructionism and cognitive linguistics. The Verbal Communication of Emotions. Interdisciplinary Perspectives (pp. 109-124). Mahwah, New Jersey: Lawrence Erlbaum Associates.

Kövecses, Z. (2005). Metaphor in culture: Universality and variation. Cambridge: Cambridge University Press.

Lakoff, G. (1980). Metaphors We Live By/George Lakoff, Mark Johnson. Chicago: University of Chicago Press.

Lakoff, G. (2001). Metaphors of terror. In These Times.

Lakoff, G. (2003). Metaphor and war, again. Alternet.

Lakoff, G., \& Johnson, M. (1999). Philosophy in the flesh: The embodied mind and its challenge to western thought: Basic books.

Lakoff, G., \& Johnson, M. (2003). Metaphors we live by. 1980. Chicago: U of Chicago P.

Lakoff, G., \& Turner, M. (1989). More than cool reason: The power of poetic metaphor. Univ. of California at Berkeley, Berkeley.

Lakoff, G., \& Turner, M. (2009). More than cool reason: A field guide to poetic metaphor. Chicago: University of Chicago Press.

Lakoff, J. (1980). Lakoff G., Johnson M. Metaphors we live by.

Lovejoy, A. O. (1936). The Great Chain of Being: A Study of the History of an Idea. The William James Lectures Delivered at Harvard University, 1933, by Arthur O. Lovejoy. Harvard: Harvard University Press.

Manzur, I. (1997). Lisan al-'arab, 20. In Muhammad 'Abd al-Wahhab (Ed.). Beirut: Dar al-Ihya 'al-Turath al-'Arabi.

Mio, J. S. (1996). Metaphor, politics, and persuasion. Metaphor: Implications and applications, 127-146.

Murray, K., \& Rosamund, M. (2006). Introducing metaphor. London/New York.

Musolff, A. (2004). Metaphor and political discourse. New York, London: Springer. 
Musolff, A. (2006). Metaphor scenarios in public discourse. Metaphor and symbol, 21(1), 23-38.

sawalif.). Retrieved 1/8/2016, from www.sawalief.com

Semino, E. (2008). Metaphor in discourse. Cambridge: Cambridge University Press.

Talebinejad, M. R., \& Dastjerdi, H. V. (2005). A cross-cultural study of animal metaphors: When owls are not wise! Metaphor and Symbol, 20(2), 133-150.

Torlakova, L. (2014). Metaphors of the Arab Spring: Figurative construals of the uprisings and revolutions. Journal of Arabic and Islamic Studies, 14, 1-25.

Van Dijk, T. A. (1998). Discourse and ideology. Discourse and Society, 9, 307-308.

Zhang, C. H., Zhang, M. H., Wang, S. Y., Han, R. J., Cao, Y. F., Hua, W. Y., ...Wei, C. C. (2010). Interactions between gut microbiota, host genetics and diet relevant to development of metabolic syndromes in mice. The ISME Journal, 4(2), 232-241.

Zoltán, K. (2002). Metaphor. A Practical Introduction. Oxford: Oxford University Press.

\section{Copyrights}

Copyright for this article is retained by the author, with first publication rights granted to the journal.

This is an open-access article distributed under the terms and conditions of the Creative Commons Attribution license (http://creativecommons.org/licenses/by/4.0/). 